\title{
SOCIAL SECURITY AND POST-RETIREMENT BENEFITS OF DEVELOPING COUNTRIES: THE CASE OF BANGLADESH
}

\author{
Monsurur Rahman, Indiana University of Pennsylvania, Indiana, Pennsylvania, U.S.A. \\ Geoffrey Tickell, Indiana University of Pennsylvania, Indiana, Pennsylvania, U.S.A. \\ Reza Karim, Independent Consultant, Ann Arbor, Michigan, U.S.A.
}

dx.doi.org/10.18374//JBR-19-3.2

\begin{abstract}
Bangladesh is undergoing rapid economic growth. With the economic growth, it is also undergoing rapid social change. Population is moving from rural to urban areas. Majority of is population is very young. When they reach the retirement age, the traditional safety net of extended family: "children taking care of their parents during their old age", may not be there. This paper discusses the social security systems of Bangladesh and USA; it will explore how a developing country like Bangladesh can benefit by emulating the US system.
\end{abstract}

Keywords: Social Security, Pension, Post-Retirement 